\title{
Paget's disease: a unique case snippet
}

\author{
Sahana Shetty, Nitin Kapoor, Anne Jennifer Prabhu, Thomas Vizhalil Paul
}

Christian Medical College Vellore, Tamil Nadu, India

\section{Correspondence to} Dr Thomas Vizhalil Paul, thomasvpaul@yahoo.com

Accepted 16 December 2013
CrossMark

To cite: Shetty S, Kapoor N, Prabhu AJ, et al. BMJ Case Rep Published online: [please include Day Month Year] doi:10.1136/bcr-2013202955

\section{DESCRIPTION}

Paget's disease (PD) is a chronic metabolically active bone disease, characterised by a disturbance in bone remodelling due to an increase in osteoblastic and osteoclastic activity. We report a case of a 58-year-old man who presented with insidious onset low backache of 3-year duration. There was no history of chronic illness, alcoholism, hypogonadism or any medications which could impair bone health. His clinical examination was unremarkable except for tenderness over the lumbar spine. The patient's spine X-ray (figure 1) showed compression fractures of lumbar vertebrae L4-L5. Differential diagnosis considered was multiple myeloma, metastasis, lymphoma, osteosarcoma and PD.

His biochemical investigations revealed a normal serum calcium, phosphorus, 25-hydroxy vitamin D, parathyroid hormone, testosterone, prostate specific antigen and serum electrophoresis. His alkaline phosphatase level was elevated (557 U/L (normal 40-125)). Bone scan showed an intense abnormal activity in the entire skull, lower thoracic and lumbar vertebrae and pelvic bones (figure 2). Biopsy of the L4 vertebra showed trabeculae of cortical and cancellous bone with intervening fibrotic marrow. The cancellous bone appeared thickened

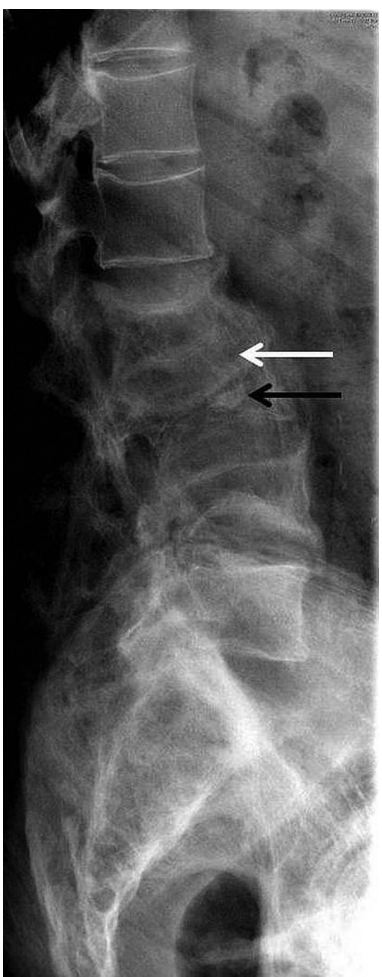

Figure 1 Compression fractures of lumbar vertebrae L4-L5.

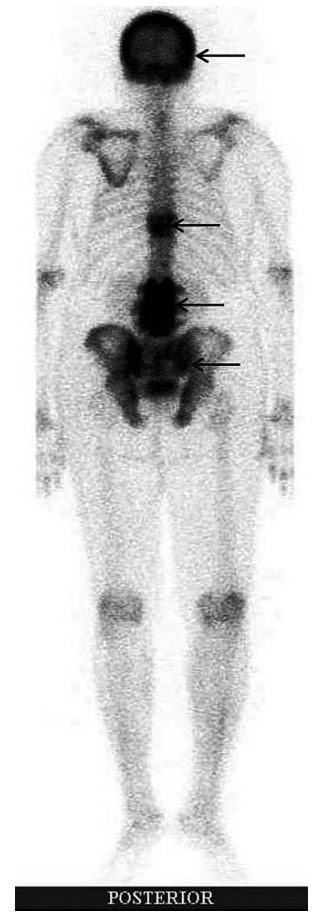

Figure 2 Bone scan showing increased uptake in the skull, spine and pelvis.

with prominent irregular cement lines, resembling jigsaw pattern and increase in osteoclastic and osteoblastic activity with new bone formation, which was consistent with PD (figure 3 ). He was initiated on bisphosphonate therapy with which there was significant clinical improvement.

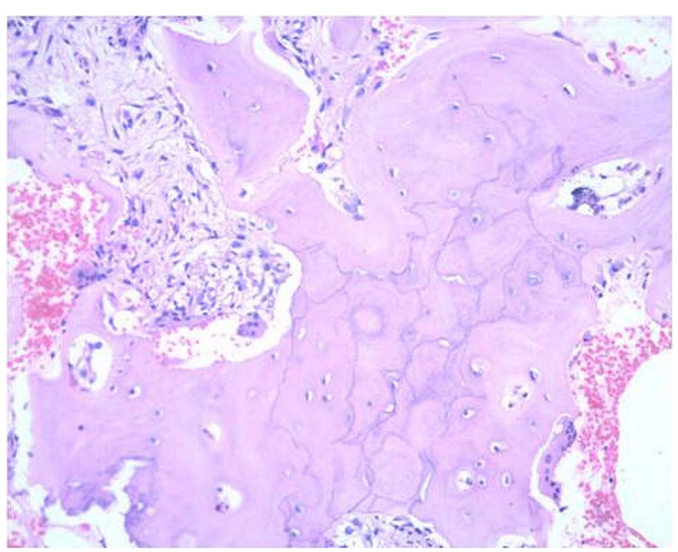

Figure $3 \quad$ L4 vertebra showing trabeculae of cortical and cancellous bone with intervening fibrotic marrow. 


\section{Learning points}

- Paget's disease (PD) is polyostotic in $66 \%$ of cases of which about $35-50 \%$ have spinal involvement, more commonly L4-L5 (58\%). ${ }^{1}$

- Back pain is the common symptom associated with PD of the spine. ${ }^{2}$

- Causes of backache in PD include periosteal stretching, vascular engorgement, microfractures, facet arthritis, intervertebral disc disease, overt fractures of vertebrae, spondylolysis, spondylolisthesis and sarcoma. ${ }^{3}$

- A high index of clinical suspicion for various manifestations and imaging characteristics of PD may help in timely diagnosis and management.
Contributors SS and NK collected the patient information and wrote the manuscript. AJP and TVP reviewed the manuscript and edited and approved the final version.

Competing interests None.

Patient consent Obtained.

Provenance and peer review Not commissioned; externally peer reviewed.

\section{REFERENCES}

1 Saifuddin A, Hassan A. Paget's disease of the spine: unusual features and complications. Clin Radiol 2003;58:102-11.

2 Altman RD, Brown M, Gargano F. Low back pain in Paget's disease of bone. Clin Orthop Relat Res 1987;217:152-61.

3 Dell'Atti C, Cassar-Pullicino VN, Lalam RK, et al. The spine in Paget's disease. Skeletal Radiol 2007;36:609-26.

Copyright 2014 BMJ Publishing Group. All rights reserved. For permission to reuse any of this content visit

http://group.bmj.com/group/rights-licensing/permissions.

BMJ Case Report Fellows may re-use this article for personal use and teaching without any further permission.

Become a Fellow of BMJ Case Reports today and you can:

- Submit as many cases as you like

- Enjoy fast sympathetic peer review and rapid publication of accepted articles

- Access all the published articles

- Re-use any of the published material for personal use and teaching without further permission

For information on Institutional Fellowships contact consortiasales@bmjgroup.com

Visit casereports.bmj.com for more articles like this and to become a Fellow 